Jurnal_ep, Vol. 11 No. 1, Maret 2021

\title{
PENGEMBANGAN INSTRUMEN HASIL BELAJAR PPKN DAN SIKAP SOSIALSISWA KELAS V SD
}

\author{
K.A.Y. Kawi ${ }^{1}$, I.W. Lasmawan ${ }^{2}$, I.M. Gunamantha ${ }^{3}$ \\ ${ }^{123}$ Program Studi Pendidikan Dasar \\ Universitas Pendidikan Ganesha \\ Singaraja, Indonesia \\ e-mail: ayu.yunita@undiksha.ac.id ${ }^{1}$, wayan.lasmawan@undiksha.ac.id ${ }^{2}$, \\ made.gunamantha@undiksha.ac.id ${ }^{3}$
}

\begin{abstract}
Abstrak
Penelitian ini bertujuan untuk mengembangkan instrumen hasil beljar PPKn dan sikap sosial pada siswa kelas V SD yang valid dan reliabel. Penelitian ini menggunakan rancangan penelitian dan pengembangan dengan model pengembangan 4-D. Model ini terdiri atas empat tahap utama yaitu define, design, develop, dan disseminate. Hasil penelitian ini yaitu, (1) Pada tahap define, telah disusunnya kisi-kisi instrumen hasil belajar PPKn dan kisi-kisi instrumen sikap sosial. (2) Pada tahap design, kisi-kisi tersebut dijabarkan menjadi instrumen hasil belajar PPKn berupa tes pilihan ganda serta instrumen sikap sosial berupa angket yang pada awalnya masing-masing terdiri dari 30 butir soal. (3) Pada tahap develop, telah dilakukan uji validitas isi instrumen hasil belajar PPKn mendapatkan hasil sebanyak 27 butir soal dinyatakan valid. Uji validitas isi instrumen sikap sosial mendapatkan hasil sebanyak 25 butir soal dinyatakan valid. Kemudian uji reliabilitas instrumen hasil belajar PPKn memperoleh hasil $r_{11} 0,76 \geq 0,70$, maka instrumen hasil belajar PPKn dinyatakan reliable. Uji reliabilitas instrumen sikap sosial memperoleh hasil $r_{11} 0,78 \geq 0,70$, maka instrumen sikap sosial dinyatakan reliable. Dengan demikian pengembngan instrumen hasil belajar PPKn dan sikap sosial dalam penelitian ini dinyatakan valid dan reliabel serta dapat dijadikan contoh untuk mengukur serta mengembangkan instrumen hasil belajar PPKn dan instrumen sikap sosial siswa kelas V.
\end{abstract}

Kata kunci: Hasil Belajar PPKn; Instrument; Sikap Sosial

\begin{abstract}
This study aimed to develop the civics learning result instruments and the social attitude of the fifth grade students which are valid and reliable. This research used research and development design with 4-D development model. This model consisted of four main stages namely define, design, develop and disseminate. The results of this study are, (1) At the define stage, the blue print of the civics learning result instrument and social attitude instrument are formed (2) At the design stage, the blue prints are described into civics learning result instruments in the form of multiple choice test as well social attitude instruments in the form of questionnaire which initially each instruments consisted of 30 items. (3) In the develop stage, the content validity test of the civics learning result instruments is done resulting 27 items are valid. The content validity test of the social attitude instruments shows the result that 25 items are valid. Then the reliability test of the civics learning result instruments obtained $r 11$ of 0.76. It means that the civic learning results instruments are reliable. Reliability test of the social attitude instruments obtains $r 11$ of 0.78 . It means that the social attitude instruments are reliable. Thus, the development of the civics learning result and social attitude instruments in this study are declared valid and reliable and are able to be used as an example to measure and develop the civics learning result instruments and the social attitude instruments of the fifth grade students.
\end{abstract}

Keywords: Civics Learning Results; Instruments Social Attitude 


\section{PENDAHULUAN}

Keberhasilan suatu pembelajaran adalah pada saat siswa telah mendapatkan pengalaman belajarnya. Keberhasilan siswa dalam belajar tergantung pada dua hal yaitu faktor dari siswa dan faktor dari guru. Tingkat keberhasilan suatu pembelajaran dapat dilihat dari hasil belajar. Hasil belajar adalah kemampuan yang didapatkan oleh siswa setelah mengikuti pembelajaran (Susanto, 2016:5). Hasil belajar dapat dilihat dari perubahan positif yang terjadi pada aspek pengetahuan, nilai, sikap dan keterampilan seseorang (Subur, 2015:12). Hasil belajar merupakan simbol keberhasilan guru dalam membelajarkan siswanya sehingga mendapatkan pencapaian yang maksimal (Yusuf, 2015:181). Berdasarkan pendapat tersebut dapat disimpulkan bahwa hasil belajar merupakan kemampuan yang diperoleh siswa dilihat dari perubahan positif yang terjadi sehingga siswa mendapatkan pencapaian yang maksimal setelah mengikuti proses pembelajaran. Hasil belajar mencakup tiga ranah atau aspek yang dapat dijadikan landasan dalam melaksanakan pembelajaran yang meliputi pengetahuan, sikap dan keterampilan.

Kegiatan pembelajaran merupakan suatu cara untuk mendapatkan suatu pengetahuan dan pengalaman belajar yang melibatkan proses kognitif dari siswa. Pengalaman belajar yang diperoleh siswa tidak hanya semata-mata pada proses kognitif saja, namun dilihat pula pada sikap dan tingkah laku dari siswa tersebut. Muatan pelajaran yang sangat erat kaitannya dengan pembentukan pola tingkah laku dan sikap yang baik pada siswa adalah PPKn.

PPKn merupakan muatan pelajaran yang paling sering muncul dalam kegiatan pembelajaran untuk mengembangkan nilai, sikap dan kepribadian yang sesuai dengan Pancasila, UUD 1945, cinta tanah air dan berwawasan kebangsaan. PPKn memuat tentang materi moral dan karakter. Hal tersebut pastinya dapat membentuk prilaku yang baik dalam kehidupan sehari-hari. PPKn dapat digunakan sebagai alat untuk membina, membimbing serta mengembangkan kognitif siswa supaya dapat menjadi pribadi yang memiliki karakter unggul. Pembentukan karakter unggul berkaitan erat dengan sikap. Perilaku dan perbuatan saling berhubungan dengan sikap. Seseorang dalam bersikap dengan orang lain disekitarnya akan membentuk sikap sosial. Sikap sosial merupakan salah satu sikap yang termuat dalam pembelajaran PPKn. Guru tentunya mampu mengkondisikan hal-hal yang telah terjadi, dengan memberikan pembaharuan kepada siswa bagaimana cara agar pada saat proses pembelajaran terutamapada mata pelajaran PKn siswa tertarik untuk mengikutinya dengan rasa gembira (Widiani, 2020). Hal ini berhubungan dengan penguasaan siswa terhadap kompetensi pengetahuan, sikap dan keterampilan.

Sikap sosial adalah tindakan individu yang mempunyai makna atau arti subjektif bagi dirinya dan diarahkan kepada tindakan orang lain. Sikap sosial dapat berupa tindakan subjektif yang terjadi karena pengaruh positif dari situasi tertentu atau merupakan tindakan berulang secara sengaja sebagai akibat dari pengaruh situasi tertentu. Sikap sosial dapat terjadi pada suatu kelompok sosial. Sekolah merupakan salah satu kelompok sosial yang terdapat beranekaragam karakter. Dalam perbedaan karakternya dapat ditemui pada kelompok belajar siswa dalam mengikuti proses pembelajaran. Dalam proses pembelajaran sangat diperlukannya peran guru dalam mengendalikan sikap sosial siswa, baik dengan individu maupun klasikal. Sikap sosial dapat terbentuk salah satunya melalui interaksi sosial. Interaksi sosial merujuk pada hubungan yang dinamis antar individu atau kelompok sosial. Interaksi sosial di sekolah terjadi dalam berbagai bentuk, misalnya kerjasama, persaingan, dan perbedaan pendapat. Maka untuk menumbuhkan sikap sosial pada siswa, dapat dilakukan dengan membangun sikap sosial yang baik di sekolah.

Sikap sosial dapat terbentuk berdasarkan cara bersikap kepada orang lain. Sikap sosial akan menimbulkan 
interaksi dan komunikasi dengan orang banyak, sehingga dapat saling bekerja sama. Proses pembelajarang yang baik harus lebih banyak mengenalkan, mengajarkan dan menceritakan sikap sosial kepada siswa. Terbentuknya sikap sosial yang positif pada siswa akan berkorelasi positif pula dengan hasil belajar PPKn begitu pula sebaliknya.

Pencapaian hasil belajar PPKn yang maksimal tidak terlepas dari peran sikap sosial siswa. Sikap sosial bukan hal yang dapat terabaikan. Oleh karena itu melakukan pengukuran terhadap sikap sosial siswa sangat diperlukan. Hasil belajar PPKn didapatkan siswa setelah melewati proses belajar. Guru tentunya harus sudah menguasai materi PPKn dengan baik dan sekaligus dapat membimbing serta mendidik siswa dengan baik agar siswa mendapatkan pengalaman belajar yang bermakna. Peran guru dalam pembelajaran adalah sebagai fasilitator, mediator, dan pembimbing. Keberhasilan pembelajaran diukur berdasarkan pada ketercapaian kompetensi yang ditetapkan sejak awal kegiatan pembelajaran. Guru dan siswa harus bekerja sama sedemikian rupa, saling mendukung sehingga memungkinkan tercapainya kompetensi yang ditetapkan. Untuk melaksanakan kegiatan belajar mengajar diperlukan langkah-langkah pembelajaran agar tujuan yang ditetapkandapat dicapai.

Hal tersebut dapat menumbuhkan motivasi belajar siswa, sehingga hasil belajar PPKn dapat tercapai secara makasimal. Memperoleh ketercapaian hasil belajar dapat melalui alat penilaian berupa instrumen.

Instrumen dapat dinyatakan sebagai alat untuk memudahkan seseorang dalam mencapai tujuan secara efektif dan efisien (Arikunto, 2015). Dalam melaksanakan tugas seseorang memerlukan alat yang tepat sehingga dapat menyelesaikan tugas tersebut dengan baik. Instrumen dalam pendidikan digunakan sebagai alat penilaian pembelajaran. Yusuf (2015) menjelaskan bahwa instrumen sebagai alat penilaian membantu menyediakan informasi untuk menjelaskan, mengungkapkan maupun menerangkan tentang suatu kejadian dan kegiatan pendidikan khususnya pada proses pembelajaran. Usaha-usaha yang dilakukan dalam meningkatkan mutu pendidikan hendaknya dimulai dari peningkatan kualitas guru. Guru yang berkualitas diantaranya adalah mengetahui dan mengerti peran dan fungsinya dalam proses pembelajaran. Guru yang berkualitas selalu fleksibel mengikuti perkembangan kurikulum dan selalu terdepan dalam menyerap maupun mengimplementasikan berbagai informasiinformasi baru kepada siswanya.

Ayu (2018) menyatakan bahwa guru adalah faktor penentu keberhasilan proses pembelajaran yang berkualitas, sehingga guru juga tentunya dapat megembangkan instrumen yang berkualitas. Berhasil tidaknya pendidikan mencapai tujuan selalu dihubungkan dengan kualitas para guru. Instrumen yang baik harus mampu mengukur dan konsisten terhadap aspek yang akan diukur (Yusuf, 2015). Menurut Covacevich (2014) semakin baik kualitas suatu instrumen, maka semakin bermanfaat, semakin tepat nilai yang diperoleh dan semakin besar kepercayaan diri dalam memberikan nilai. Menurut Yusuf (2015) menyatakan bahwa instrumen yang baik memenuhi persyaratan, yaitu valid, reliabel, objektif, praktis dan mudah dilaksanakan serta norma. Covacevich (2014) menyatakan dua aspek utama yang sangat mempengaruhi kualitas suatu instrumen adalah validitas dan reliabilitasnya.

Instrumen berfungsi untuk memperoleh data yang diperlukan ketika siswa telah melewati proses pembelajaran sampai akhir. Terdapat dua jenis instrumen, yaitu tes dan non tes. Instrumen tes dapat menilai kemampuan kognitif siswa seperti hasil belajar PPKn. Instrumen non tes dapat menilai kemampuan non kognitif siswa seperti sikap sosial. Adapun jenis-jenis instrumen dibedakan menjadi dua yaitu intrumen tes dan non tes. Instrumen tes merupakan suatu alat penilaian yang komprehensif untuk memperoleh data atau informasi melalui pertanyaan atau latihan. Bentukbentuk instrumen tes yaitu sebagai berikut. (1) Tes subjektif, disebut sebagai tes dengan menggunakan pertanyaan terbuka, karena dalam tes tersebut siswa 
diharuskan menjawab sesuai dengan pengetahuan yang dimilikinya. Tes subjektif umumnya berbentuk esai (uraian). Siswa akan mengingat pelajaran kembali dan menjawabnya melalui pembahasan atau uraian kata. Tes esai meminta siswa untuk menjelaskan, menginterpretasikan dan membedakan dalam bentuk pertanyaan yang dapat menunjukkan siswa mengerti terhadap materi yang dipelajari. (2) Tes objektif, dilakukan secara objektif dalam pemeriksaannya untuk mengatasi kelemahan dari tes esai. Macam-macam tes objektif meliputi: a) Tes benar-salah (true-false) mencakup pernyataanpernyataan ada yang benar dan ada yang salah, b) Tes pilihan ganda (multiple choice test) yaitu setiap pertanyaan atau pernyataan mempunyai beberapa pilihan jawaban yang salah, tetapi disediakan satu pilihan jawaban yang benar (Arifin, 2014:139), c) Tes isian (completion test) yaitu tes untuk melengkapi kalimat yang dihilangkan dan d) Tes menjodohkan (matching) yaitu memasangkan atau mencocokan pertanyaan dengan jawaban yang disediakan.

Instrumen nontes digunakan untuk mengukur perubahan tingkah laku yang berhubungan dengan aspek afektif dan psikomotor termasuk apa yang dikerjakan siswa. Bentuk-bentuk nontes yaitu sebagai berikut: (1) Skala bertingkat (rating scale), menggambarkan suatu nilai yang berbentuk angka terhadap hasil pertimbangan dengan meletakkan angka dari yang rendah ke yang tinggi. (2) Kuesioner (questionair), digunakan untuk mengetahui data diri seseorang melalui daftar pertanyaan atau pernyataan. Kuesioner disebut juga angket. Daftar cocok (check list), merupakan daftar penyataan untuk responden dengan cara membubuhkan tanda cocok $(\sqrt{ })$ pada tempat yang disediakan. (3) Wawancara (insterview), merupakan suatu cara untuk mendapat informasi melalui jawaban responden dengan melakukan tanyajawab. (4) Pengamatan (observation), merupakan suatu teknik dengan cara mengadakan pengamatan serta pencatatan secara sistematis. (5) Riwayat hidup, merupakan suatu teknik untuk mempelajari keadaan seseorang untuk memperoleh gambaran selama masa hidupnya.

Memperoleh hasil belajar yang optimal harus menggunakan instrumen yang berkualitas. Namun yang terjadi adalah banyak instrumen hasil belajar PPKn hanya terpaku pada contoh yang sudah ada dan kurang mengaitkan pada fenomena-fenomena terkini. Pembuatan instrumen hasil belajar PPKn pada kenyataannya juga hanya mencakup dimensi kognitif yang rendah yaitu $\mathrm{C} 1$ dan C2 (mengetahui dan memahami). Hal tersebut ditemukan pada soal PH, PTS, PAS maupun soal-soal yang ada pada buku siswa khususnya pada muatan pelajaran PPKn. Banyak yang belum dapat mencakup dimensi kognitif tinggi untuk siswa. Menyebabkan kemampuan berpikir tingkat tinggi siswa tidak terukur dan kurang terasah, sehingga hasil belajar siswa tidak dapat diketahui dengan pasti. Kemudian untuk instrumen non kognitif seperti penilaian sikap sosial sangat jarang temukan. Sering kali penilaian sikap sosial dilakukan secara subjektif sehingga data yang diperoleh tidak valid.

Permasalahan yang belum banyak mendapat perhatian tersebut dapat teratasi dengan melakukan pengembangan instrumen. Berupa pengembangan instrumen hasil belajar PPKn dan instrumen sikap sosial. Adanya pengembangan instrumen ini akan menjadikan pengukuran terhadap kemampuan kognitif maupun non kognitif siswa menjadi lebih optimal. Pengaplikasian hal tersebut mampu mengembangkan kemampuan pemahaman tingkat tinggi siswa. Serta data yang didapatkan menjadi valid. Hal ini didukung juga dalam penelitian Hardiani (2017) yang menyampaikan bahwa proses penilaian hasil belajar siswa memerlukan instrumen yang harus dipersiapkan dan diperhatikan terlebih dahulu, agar tujuan pembelajaran dapat tercapai secara optimal. Sejalan dengan pendapat tersebut dalam penelitian Kuntoro dan Wardani (2020) menyatakan bahwa proses penilaian sikap siswa memerluan instrumen yang perlu dipersiapkan karena berkaitan dengan aspek tang sulit diukur. 
Fadilah, dkk (2017) menyatakan bahwa dengan mengembangkan instrumen penilaian pada materi PPKn sebagai upaya untuk meningkatkan keaktifan dan prestasi belajar siswa. Sejalan dengan pendapat tersebut penelitian Brata, dkk (2020) menyatakan bahwa hasil dari penilaian sikap siswa dengan instrumen yang telah dikembangkan menunjukkan kategori baik. Kemudian menurut Prasanti (2017) pengembangan berupa instrumen penilaian sikap sosial pada pembelajaran tematik kelas IV SD yang dikategorikan sebagai produk pengembangan yang tepat digunakan untuk menilai sikap sosial siswa.

Tujuan penelitian ini adalah untuk mengetahui validitas isi instrumen hasil belajar PPKn, validitas isi instrumen sikap sosial, reliabilitas menurut expert instrumen hasil belajar PPKn, reliabilitas menurut expert instrumen sikap sosial pada siswa kelas V SD.

\section{METODE}

Penelitian ini menggunakan rancangan penelitian dan pengembangan yang dikenal dengan istilah Research and Development (R\&D). Subjek penelitian ini yaitu siswa kelas V SD. Tahap periode perkembangan menurut Piaget bahwa anak usia sekolah dasar berada pada tahapan operasional konkret. Pada tahap ini siswa sudah mampu berpikir sistematis mengenai benda dan peristiwa yang konkret. Siswa kelas V SD memiliki kemampuan memecahkan masalah (problem solving), menyusun strategi dan mampu menghubungkan (Susanto, 2016). Siswa pada usia ini pada umumnya memiliki kemampuan intelektual seperti rasa ingin tahu terhadap yang ia pelajari. Kemampuan ini perlu difasilitasi guru agar siswa tidak hanya menerima informasi yang diterima namun juga dapat mengolah informasi tersebut.

Produk yang dikembangkan berupa instrumen hasil belajar PPKn dan instrumen sikap sosial siswa kelas V SD. Model pengembangan yang digunakan dalam penelitian ini yaitu model pengembangan 4-D (Four D). Model ini dikembangkan oleh Thiagarajan yang terdiri atas empat tahap utama yaitu: (1)
Define (Pendefinisian) meliputi analisis kebutuhan dengan mengumpulkan berbagai informasi yang diperlukan terkait kualitas instrumen yang kurang baik. Berdasarkan analisis kebutuhan dilakukan analisis teoretik untuk menemukan grand teori yaitu dimensi dan indikator dari hasil belajar PPKn dan sikap sosial untuk menyusun kisi-kisi instrumen. (2) Design (Perancangan) adalah kegiatan untuk menjabarkan kisi-kisi menjadi instrumen. Jenis instrumen hasil belajar PPKn yaitu tes Pilihan Ganda (PG). Jenis instrumen sikap sosial, yaitu angket dengan rentangan skala 1-5. (3) Develop (Pengembangan) adalah kegiatan mengujicoba instrumen yang didesain untuk mencari validasi instrumen. Validasi instrumen meliputi validitas isi dengan expert dan reliabilitas. Validitas isi instrumen hasil belajar PPKn dan sikap sosial menggunakan CVR. Reliabilitas instrumen hasil belajar PPKn menggunakan Kuder Richadson (KR-20) sedangkan instrumen kemampuan sikap sosial menggunakan Alpha Cronbach. Pada penelitian ini dilakukan sebanyak 1 kali penilian oleh 5 orang expert yang terdiri dari 2 orang ahli dan 3 orang praktisi pendidikan. (4) Disseminate (Penyebaran) merupakan tahap menyebarluaskan instrumen hasil belajar PPKn dan sikap sosial agar mengetahui efektivitas dari instrumen tersebut. Kemudian akan dilakukan pengemasan, difusi dan adaptasi agar instrumen hasil belajar PPKn dan sikap sosial pada penelitian ini dapat digunakan oleh pihak lain khususnya pada guru kelas $\mathrm{V}$ di sekolah dasar. Namun tahap disseminate pada penelitian ini tidak dapat dilakukan karena adanya situasi kesehatan masyarakat yang tidak memungkinkan untuk menyebarluaskan instrumen akibat penyebaran Covid-19. Situasi ini menyebabkan pemerintah menghimbau masyarakat agar bekerja dan belajar dari rumah untuk memutus rantai penyebaran virus tersebut.

Metode pengumpulan data
merupakan suatu prosedur yang menjelaskan cara perolehan data dalam suatu penelitan. Secara umum metode pengumpulan data dibedakan menjadi dua, yaitu metode tes dan metode nontes 
(Agung, 2104). Metode nontes terdiri dari (1) metode observasi, (2) metode interview/wawancara, (3) metode kuesioner/angket. Metode pengumpulan data baik dalam bentuk tes maupun nontes mempunyai fungsi masing-masing yang berbeda sesuai dengan jenis metode yang akan digunakan. Perbedaan yang mendasar antara metode tes dan nontes terletak pada jawaban yang diberikan. Dalam tes hanya terdapat kemungkinan jawaban benar atau salah, apabila jawaban tidak sesuai dengan kunci maka jawaban akan dinyatakan salah. Sedangkan dalam metode nontes tidak ada jawaban benar maupun salah, jawaban tergantung pada keadaan seseorang.

Adapun metode pengumpulan data dalam penelitian disajikan pada tabel 1 sebagai berikut.

Tabel 1. Metode dan Instrumen Pengumpulan Data

\begin{tabular}{lllll}
\hline No & \multicolumn{1}{c}{ Data } & \multicolumn{1}{c}{$\begin{array}{c}\text { Metode } \\
\text { Pengumpulan } \\
\text { Data }\end{array}$} & Bentuk Instrumen & \multicolumn{1}{c}{ Validasi Instrumen } \\
\hline 1. & $\begin{array}{l}\text { Instrumen } \\
\text { hasil belajar }\end{array}$ & Tes & Pilihan Ganda & $\begin{array}{l}\text { a. Validitas isi } \\
\text { b. Reliabilitas menurut } \\
\text { PPKn }\end{array}$ \\
$\begin{array}{l}\text { Instrumen } \\
\text { Sikap Sosial }\end{array}$ & Nontes & Angket & $\begin{array}{l}\text { expert } \\
\text { a. Validitas isi } \\
\text { b. Reliabilitas menurut } \\
\text { expert }\end{array}$ \\
\hline
\end{tabular}

\section{HASIL DAN PEMBAHASAN}

Hasil pengembangan ini difokuskan pada pengembangan instrumen hasil belajar PPKn dan sikap sosial pada siswa kelas V. Produk yang dikembangkan adalah instrumen kognitif berupa soal tes objektif pilihan ganda dan instrumen nonkognitif berupa angket. Penelitian ini menggunakan rancangan penelitian dan pengembangan yang dikenal dengan istilah Research and Development (R\&D). Model pengembangan yang digunakan adalah model pengembangan 4-D (Four $D$ ). Tahapan ini dilakukan secara runtut dan sistematis agar mendapatkan hasil instrumen yang baik. Hasil dari tahapantahapan ini dijabarkan sebagai berikut. (1) Define (Pendefinisian) meliputi analisis kebutuhan dengan mengumpulkan berbagai informasi yang diperlukan terkait kualitas instrumen yang kurang baik. Hasil penelitian pada tahap ini berupa kisi-kisi instrumen hasil belajar PPKn dan sikap sosial yang disusun berdasarkan analisis teoretik grand teori yang terdiri dari dimensi dan indikator. (2) Design (Perancangan) adalah kegiatan untuk menjabarkan kisi-kisi menjadi butir instrumen. Hasil penelitian pada tahap ini, yaitu kisi-kisi yang telah disusun kemudian dijabarkan menjadi instrumen hasil belajar
PPKn berupa tes pilihan ganda yang pada awalnya terdiri dari 30 butir pertanyaan. Instrumen sikap sosial berupa angket yang pada awalnya terdiri dari 30 butir pernyataan. (3) Develop (Pengembangan) adalah kegiatan mengujicoba instrumen yang didesign untuk mencari validasi instrumen. Validasi instrumen meliputi validitas isi dengan expert dan reliabilitas. Validitas isi instrumen hasil belajar PPKn dan sikap sosial menggunakan CVR. Reliabilitas instrumen hasil belajar PPKn menggunakan Kuder Richadson (KR-20) sedangkan instrumen kemampuan sikap sosial menggunakan Alpha Cronbach. Pada penelitian ini dilakukan sebanyak 1 kali penilian oleh 5 orang expert yang terdiri dari 2 orang ahli dan 3 orang praktisi pendidikan. Instrumen yang telah dibuat melalui proses validasi oleh lima expert. Berikut ini adalah tanggapan umum mengenai soal-soal yang telah dibuat. (1) Pada indikator kisi-kisi, periksa kembali dimensi kognitif yang digunakan. (2) Indikator soal pada kisi-kisi yang baik adalah indikator yang spesifik mengandung isi soal. (3) Redaksi soal agar disusun lebih baik. (4) Kaitkan soal dengan kehidupan sehari-hari siswa agar peristiwa tampak nyata. (5) Pada indikator kisi-kisi, periksa kembali dimensi pengetahuan yang digunakan. (6) Pada 
indikator kisi-kisi, periksa kembali dimensi kognitif yang digunakan. (7) Redaksi soal agar disusun lebih baik. (8) Memilih nama daerah dan nama orang disesuaikan dengan lingkungan siswa. (9) Redaksi soal dalam satu kalimat agar tidak terlalu panjang. (10) Penggunaan kalimat sebaiknya lebih efektif. (11) Perhatikan penggunaan tanda maupun singkatan. Masing-masing expert memberikan penilaian dari aspek materi, bahasa dan konstruksi.
Selanjutnya adalah melakukan uji validitas isi dengan teknik Lawshe, yakni rasio validitas isi atau content validity ratio (CVR). Untuk setiap item, masing-masing pakar menilai apakah item itu "relevan", "kurang relevan", atau "tidak relevan". Validitas isi dengan rumus CVR digunakan pada instrumen hasil belajar PPKn dan sikap sosial. Adapun hasil yang diperoleh disajikan pada tabel 2.

Tabel 2. Hasil Uji Validitas Isi dan Reliabilitas Instrumen

\begin{tabular}{clcc}
\hline \multirow{2}{*}{ NO } & \multicolumn{1}{c}{ Instrumen } & Hasil Analisis \\
& & Uji Validitas Isi & Uji Reliabilitas \\
\hline 1 & Hasil Belajar PPKn & 27 butir valid & 0,76 \\
2 & Sikap Sosial & 25 butir valid & 0,78 \\
\hline
\end{tabular}

Instrumen hasil belajar PPKn mendapatkan hasil sebanyak 27 butir soal dinyatakan valid. Uji validitas isi instrumen sikap sosial mendapatkan hasil sebanyak 25 butir soal dinyatakan valid. Kemudian uji reliabilitas instrumen hasil belajar PPKn memperoleh hasil $r_{11} 0,76 \geq 0,70$, maka instrumen hasil belajar PPKn dinyatakann reliable. Uji reliabilitas instrumen sikap sosial memperoleh hasil $r_{11} 0,78 \geq 0,70$, maka instrumen sikap sosial dinyatakan reliable. Dengan demikian pengembngan instrumen hasil belajar PPKn dan sikap sosial dalam penelitian ini dinyatakan valid dan reliabel serta dapat dijadikan contoh untuk mengukur serta mengembangkan instrumen hasil belajar PPKn dan instrumen sikap sosial siswa kelas V.

Hasil penelitian ini yaitu, validitas isi instrumen hasil belajar PPKn pada siswa kelas V SD dilakukan oleh lima orang expert yang memberikan penilaian rentang 1-3 dengan kategori "relevan", "kurang relevan" dan "tidak relevan" pada setiap butir soal. Pada awalnya banyak butir soal pada instrumen hasil belajar PPKn adalah 30 butir. Expert memberikan saran dalam hal konstruksi dan bahasa sehingga perlu adanya revisi. Terdapat 3 butir soal yang tidak memenuhi kriteria butir soal yang valid. Kriteria isi butir dinyatakan valid apabila memiliki $C V R \geq 0.60$. Butir soal yang tidak valid tersebut diantaranya butir nomor 7 dengan hasil CVR 0,2; butir nomor 11 dengan hasil CVR 0,2; butir nomor 28 dengan hasil CVR 0,2. Hasil uji validitas isi instrumen hasil belajar PPKn menunjukkan bahwa terdapat 27 butir soal yang valid.

Validitas isi instrumen sikap sosial pada siswa kelas V SD dilakukan oleh lima orang expert yang memberikan penilaian rentang 1-3 dengan kategori "relevan", "kurang relevan" dan "tidak relevan" pada setiap butir soal. Pada awalnya banyak butir soal pada instrumen sikap sosial adalah 30 butir. Expert memberikan saran dalam hal konstruksi dan bahasa sehingga perlu adanya revisi. Terdapat 5 butir soal yang tidak memenuhi kriteria butir soal yang valid. Kriteria isi butir dinyatakan valid apabila memiliki CVR $\geq 0.60$. Butir soal yang tidak valid tersebut diantaranya butir nomor 15 dengan hasil CVR 0,2; butir nomor 22 dengan hasil CVR 0,2; butir nomor 28 dengan hasil CVR -0,2; butir nomor 29 dengan hasil CVR 0,2; butir nomor 30 dengan hasil CVR 0,2. Hasil uji validitas isi instrumen sikap sosial menunjukkan bahwa terdapat 25 butir soal yang valid.

Reliabilitas menurut expert instrumen hasil belajar PPKn pada siswa kelas V SD dilakukan terhadap 27 butir soal yang valid. Hasil uji reliabilitas instrumen hasil 
belajar PPKn dengan analisis Kuder Richadson (KR-20) berdasarkan butir soal yang telah dinyatakan valid pada penelitian ini, yaitu $r_{11} 0,76 \geq 0,70$, maka reliabilitasnya dinyatakan reliable. Dengan demikian, 27 butir soal dapat menjadi contoh untuk mengukur dan mengembangkan instrumen hasil belajar PPKn siswa kelas V.

Reliabilitas menurut expert instrumen sikap sosial pada siswa kelas V SD dilakukan terhadap 25 butir soal yang valid. Hasil uji reliabilitas instrumen sikap sosial dengan analisis Alpha Cronbach berdasarkan butir soal yang telah dinyatakan valid pada penelitian ini, yaitu $r_{11} 0,78 \geq 0,70$, maka reliabilitasnya dinyatakan reliable. Dengan demikian, 25 butir soal dapat menjadi contoh untuk mengukur dan mengembangkan instrumen sikap sosial siswa kelas V.

Adanya pengembangan instrumen ini akan menjadikan pengukuran terhadap kemampuan kognitif maupun non kognitif siswa menjadi lebih optimal. Pengaplikasian hal tersebut mampu mengembangkan kemampuan pemahaman tingkat tinggi siswa. Serta data yang didapatkan menjadi valid. Hal ini didukung juga dalam penelitian Hardiani (2017) yang menyampaikan bahwa proses penilaian hasil belajar siswa memerlukan instrumen yang harus dipersiapkan dan diperhatikan terlebih dahulu, agar tujuan pembelajaran dapat tercapai secara optimal. Sejalan dengan pendapat tersebut dalam penelitian Kuntoro dan Wardani (2020) menyatakan bahwa proses penilaian sikap siswa memerluan instrumen yang perlu dipersiapkan karena berkaitan dengan aspek tang sulit diukur.

Fadilah, dkk (2017) menyatakan bahwa dengan mengembangkan instrumen penilaian pada materi PPKn sebagai upaya untuk meningkatkan keaktifan dan prestasi belajar siswa. Sejalan dengan pendapat tersebut penelitian Brata, dkk (2020) menyatakan bahwa hasil dari penilaian sikap siswa dengan instrumen yang telah dikembangkan menunjukkan kategori baik. Kemudian menurut Prasanti (2017) pengembangan berupa instrumen penilaian sikap sosial pada pembelajaran tematik kelas IV SD yang dikategorikan sebagai produk pengembangan yang tepat digunakan untuk menilai sikap sosial siswa.

Hasil temuan penelitian pada penelitian ini memiliki persamaan dengan penelitian yang relevan sebelumnya dan memperkuat hasil penelitian yang diperoleh. Hal ini didukung oleh hasil penelitian Fadilah, dkk (2017) yang menyimpulkan bahwa pengembangan instrumen penilaian pada materi PPKn dinyatakan valid dan reliabel untuk meningkatkan kreatifitas dan prestasi belajar siswa kelas VII SMPN 3 Malang. Kemudian hasil penelitian Hardiani (2017) menyimpulkan bahwa pengembangan instrumen penilaian sikap sosial dinyatakan valid dan reliabel untuk pembelajaran IPS kelas IV SD.

\section{PENUTUP}

Simpulan hasil penelitian yang telah dipaparkan, yakni validitas isi instrumen hasil belajar PPKn pada siswa kelas V SD, yakni terdapat 3 butir soal yang tidak memenuhi kriteria butir soal yang valid. Sehingga hasil uji validitas isi instrumen hasil belajar PPKn menunjukkan bahwa terdapat 27 butir soal yang valid. Validitas isi instrumen sikap sosial pada siswa kelas V SD, yakni Terdapat 5 butir soal yang tidak memenuhi kriteria butir soal yang valid. Sehingga hasil uji validitas isi instrumen sikap sosial menunjukkan bahwa terdapat 25 butir soal yang valid.

Reliabilitas instrumen hasil belajar PPKn dan sikap sosial pada siswa kelas $\mathrm{V}$ dinyatakan reliable. Dengan demikian, butir soal dapat menjadi contoh untuk mengukur dan mengembangkan instrumen hasil belajar PPKn dan sikap sosial siswa kelas V.

Selain itu, penelitian ini diharapkan dapat dijadikan pedoman dalam merancang pengembangan instrumen hasil belajar PPKn dan sikap sosial siswa serta dapat memberikan perubahan yang lebih baik sesuai dengan perkembangan teknologi dan informasi, maka secara otomatis tujuan pendidikan akan tercapai secara optimal. 


\section{DAFTAR RUJAKAN}

Ahmadi, Abu. 2009. Psikologi Sosial. Jakarta: PT. Rineka Cipta.

Arifin, Zainal. 2014. Evaluasi Pembelajaran. Bandung: PT. Remaja Rosdakarya Offset.

Arikunto, Suharsimi. 2015. Dasar-Dasar Evaluasi Pendidikan. Jakarta: PT. Bumi Aksara.

Ayu, Eka Sastrika. 2018. Pengembangan Instrumen Asesmen Keterampilan Belajar dan Berinovasi pada Mata Pelajaran IPA SD. Program Studi Pendidikan Dasar, Program Pascasarjana Universitas Pendidikan Ganesha Singaraja, Indonesia. Jurnal Pendidikan Dasar Indonesia, Volume 2, Nomor 2. Diakses tanggal 11 April 2020.

Azwar, Saifudin. 2003. Sikap Manusia, Teori dan Pengukurannya. Yogyakarta: Pustaka Pelajar.

Brata, Diah Nali Puji, dkk. 2020. Developing Pancasila and Civic Education (PPkn) Based on Local Wisdom. STKIP PGRI Jombang, Indonesia, Universitas Balikpapan, Indonesia, IKIP PGRI Bojonegoro, Indonesia, IAIN Ponorogo, Indonesia. GIAP Journal, Volume 8, Nomor 1 (hlm 768-773). Diakses tanggal 11 April 2020.

Covacevich, Catalina. 2014. How to Select an Instrument for Assessing Student Learning. Cataloging-in-Publication data provided by the Inter-American Development Bank Felipe Herrera Library.

Direktorat Jenderal Pendidikan Dasar dan Menengah Kementerian Pendidikan Nasional Republik Indonesia. 2016. Panduan Penilaian untuk Sekolah Dasar SD. Jakarta: Kementerian Pendidikan Nasional RI.

Djaali. 2006. Psikologi Pendidikan. Jakarta: PT. Bumi Aksara.

Depdiknas .2006. Permendiknas No 22 Tahun 2006 Tentang Standar Isi. Jakarta: Depdiknas.
Fadilah, Nur, dkk. (2017). "Pengembangan Instrumen Penilaian pada Materi PPKn Sebagai Upaya untuk Meningkatkan Keaktifan dan Prestasi Belajar Siswa Kelas VII Smpn 3 Malang". Jurusan Hukum dan Kewarganegaraan Fakultas IImu Sosial Universitas Negeri Malang Jalan Semarang No.5 Malang. Jurnal Repositori UM. Diakses tanggal 20 Maret 2020.

Hardiani, Iska Novi. (2017). "Pengembangan Instrumen Penilaian Sikap Sosial Pembelajaran IPS Kelas IV SD". FKIP Universitas Kristen Satya Wacana. Jurnal Mitra Pendidikan, Volume 1, Nomor 6 (hlm 615-628)

Kosasih, E. 2014. Strategi Belajar dan Pembelajaran Implementasi Kurikulum 2013. Bandung: Yrama Widya.

Kuntoro, Bambang Tri dan Naniek Sulistya Wardani. 2020. "Pengembangan Instrumen Penilaian SIkap Sosial Pembelajaran Tematik Kelas III SD". FKIP Universitas Kristen Satya Wacana, Kota Salatiga, Indonesia. Jurnal IImiah Wahana Pendidikan, Volume 6, Nomor 2 (hlm 163-175). Diakses tanggal 2 April 2020.

Prasanti, Rani Setia. 2017. Pengembangan Instrumen Penilaian Sikap Sosial Pada Pembelajaran Tematik Kelas IV SD. Program Studi Magister Keguruan Guru Sekolah Dasar Fakultas Keguruan Dan IImu Pendidikan (FKIP) Universitas Lampung Bandar Lampung. Jurnal Pedagogi. Diakses tanggal 2 April 2020.

Ritzer, George. 2012. Teori Sosiologi (Dari Klasik Sampai Perkembangan Terakhir Post Modern). Yogyakarta: Pustaka Belajar.

Sarwono, Sarlito W. \& Eko A. Meinarno. 2009. Psikologi Sosial. Jakarta: Penerbit Salemba Humanika. 
Smith, Mark K, dkk. 201. Teori Pembelajaran \& Pengajaran. Jogjakarta: Mirza Media Pustaka.

Subur. 2015. Pembelajaran Nilai Moral Berbasis Kisah. Yogyakarta: Kalimedia.

Sudijono, Anas. Pengantar Evaluasi Pendidikan. Jakarta: PT Rajagrafindo Persada.

Susanto, Ahmad. 2016. Teori Belajar dan pembelajaran di Sekolah Dasar. Jakarta: Prenadamedia Group.

Undang-Undang Republik Indonesia Nomor 20 Tahun 2003 tentang Sistem Pendidikan Nasional. 2003. Jakarta: Pemerintah Republik Indonesia.

Wadiyo (2007). Berkesenian: Tindakan Sosial Menurut Max Weber. Jurusan Pendidikan Sendratasik FBS UNNES. Indonesian Publication Index, Volume 3, Nomor 2 (hlm 2).

Wahab, Azis. 2007. Materi Pokok IImu Kewarganegaraan Pendidikan Kewarganegaraan. Yogyakarta: UNY.

Widiani. 2020. Pengaruh Model Pembelajaran TGT Berbantuan Permainan Tradisional terhadap Sikap Sosial dan Hasil Belajar PKn Siswa. Program Studi Pendidikan Dasar, Program Pascasarjana Universitas Pendidikan Ganesha Singaraja, Indonesia. Jurnal Pendidikan Dasar, Volume 4, Nomor 1. Diakses tanggal 22 Juli 2019.

Widoyoko, E. P. 2014. Penilaian Hasil Pembelajaran di Sekolah. Yogyakarta: Pustaka Pelajar.

Yusuf, Muri. A. 2015.Asesmen dan Evaluasi Pendidikan Pilar Penyedia Informasi dan Kegiatan pengendalian Mutu Pendidikan. Jakarta: Prenadamedia Group. 